\title{
British Residents at the Court of Nepal During the 19th Century*
}

\section{Introduction}

\author{
Dr. Tri Ratna Manandhar**
}

Nepal and the British had their first contact not as friends but as enemies, and the armies of both the countries made its beginning at the battleground of Sindhuligrahi.

After the establishment of its power in the principal areas of India (Bengal, Bombay and Madras), the English East India company realized the advantages of spreading its influence in Nepal. First, this tiny Himalayan state would serve as a hill station to the British especially in the summer season; and secondly, the British would be able to develop commercial relations with Tibet through Nepal. When King Prithvi Narayan Shah of Gorkha was expanding his kingdom and was about to capture the Kathmandu Valley, the East India company, on the request of the last Malla king of Kathmandu, dispatched an army under Captain Kinloch in 1767 to march through the plains to fight the Gorkhali king. ${ }^{1}$ Though the Gorkhali soldiers at Sindhuligarhi defeated the company's army, the British did not loose heart but continued their attempts to know the secrets of the Himalayan kingdom through several missions including that of James Logan in 1770 and Foxcroft in $1784 .^{2}$

These missions could gather certain information about Nepal but they were not sufficient to materialize the British interests in the Himalayan kingdom. In 1792, however, the British were successful in concluding a commercial treaty with Nepal. Both the parties had different objectives in signing the treaty. As in India, the British wanted to penetrate into the kingdom as traders and businessmen and establish their domination in due course. Nepal signed the treaty with the sole hope to get British help in case she was involved in a war with Tibet and China, a

* This paper was presented at the $12^{\text {th }}$ IAHA conference in Hong Kong (June 1991).

** Dr. Tri Ratna Manandhar is a Professor in the Central Department of History, Tribhuvan University, Kirtipur, Kathmandu.

1 K. C. Chaudhuri, Anglo-Nepalese Relation, Calcutta: Modern Book Agency, 1960, pp. 21-23.

2 D. R. Regmi, Modern Nepal, Vol. I, Calcutta: firma K.L. Mukhopadhyaya, 1975, pp. 399-401 and 407-408. 
seed of which had already sowed in $1788 .^{3}$ But contrary to her expectation, Nepal did not get any help from the British in her war with China, rather an 'unwanted' British mission under Captain Kirkpatrick visited the country and collected secret information about the land to the advantage of the East India company. ${ }^{4}$

Greatly annoyed by this British move, the Nepal government did not take any step to implement the commercial treaty. Maulavi Abdul Qadir Ali, a Bengali Muslim, came to Nepal in 1795 in the form of a merchant, to persuade the Nepali statesmen to implement the treaty, but the Nepali court turned deaf ear to him. ${ }^{5}$

\section{Opening of the Residency}

King Rana Bahadur Shah's renunciation of throne, in favour of his infant son, and his flight to Banaras in 1800 opened a new phase in Anglo-Nepali relations. The Nepali statesmen, who controlled the administration of the state after Rana Bahadur's exit, did not want the return of the ex-king to Nepal. In order to stop him in India, Nepal signed a treaty of friendship with the East India Company on 26 October 1801, which among others, provided for the stationing of a British Resident at Kathmandu. ${ }^{6}$ The main function of the Resident, according to the treaty, was to regularize relation between the two governments, but Captain Knox, who was appointed British Resident, was given some secret instructions to serve British interests in Nepal. He was to obtain relevant information about the civil government, its alliances and connections with other states, particularly China. He was also required to get accurate information respecting the mineral, botanical and agricultural products of Nepal and to make such arrangements with the Nepal government, which would enable the company and the British merchants to exploit the produce of Nepal. The British Resident was also duty bound to supply information about the military force such as number, types and discipline of the troops, and its internal and external defenses. Knox was cautioned to obtain all these information in a manner that would preclude any suspicion on the part of the Nepal government. ${ }^{7}$

3 Tri Ratna Manandhar, Nepal: The Years of Trouble (1877-85), Kathmandu: Purna Devi Manandhar, 1986, pp. 177-78.

4 Leo. E. Rose, Nepal - Strategy for Survival, Delhi: Oxford University Press, 1973, pp. 69-71.

5 Ibid., p. 76.

$6 \quad$ B.D. Sanwal, Nepal and the East India Company, Bombay: Asia Publishing House, 1965, p. 86.

7 Chaudhuri, f. n. no 1, pp. 120-23. 
T.R.Manandhar: British Residents at the Court ...

On his arrival at Kathmandu, as British Resident, Captain Knox was accorded a reception befitting the status and prestige of the government he represented and creditable to the Nepali administration. A new bungalow was built up in the royal garden for him and his staff, and every possible facility was provided to them. ${ }^{8}$ Soon the situation took an unexpected turn. Partly because of the political strife inside the Nepali Court, and partly due to the suspicious nature of the Resident himself, Knox was placed in a difficult position by the hostile attitude of the Nepali court. Gradually the opposition of the Nepali officials to the treaty had become so bitter that Knox had to admit that he was persona nongrata. Consequently, after twelve months of fruitless efforts to establish closer connections, the British Resident left Kathmandu in March 1803 and the treaty was formally abrogated after a few moths. ${ }^{9}$ Thus, the first attempt of the British to post a Resident in Nepal ended in failure.

With the rise of Bhimsen Thapa as de facto ruler of Nepal, following the assassination of ex-king Rana Bahadur, Anglo-Nepali relations further deteriorated. Having failed to establish their influence by peaceful means, the British now decided to use force by exploiting opportunities provided by some border disputes. Nepal knew well that the mere surrendering of the disputed areas would not solve the problem, for the border dispute was only a pretext on the part of the British to expand their sphere of influence in Nepal. Hence, despite opposition form the military officials, Bhimsen Thapa decided to oppose the British attempt by force. ${ }^{10}$ On 1 November 1814, Lord Hastings formally declared a war against Nepal, which lasted for about a year and half and was ended by the treaty of Sugauli, after the Nepali force was defeated by the huge British army. Nepal lost one-third of her territory, had to seek permission of the British to employ in her service any British, European, or American subject, and serious of all, had to accept a British Resident at Kathmandu. ${ }^{11}$ In course of negotiation, Nepal had vehemently opposed the question of posting a British Resident at the Nepali Court. Bhimsen Thapa well realized the meaning of the system of protectorates, initiated by the British in India, which ultimately would lead to the subjugation of his country to the British. The Resident was more a watchdog to expand

Ibid., p. 129

Bikrama Jit Hasrat, History of Nepal, Punjab: V.V. Research Institute, 1970, p. 216.

10 Henery T. Prinsep, History of the Political and Military Transactions in India During the Administration of the Marques of Hastings, Vol. 1, London: Kinsbury, Parbury and Allen, 1825, pp. 457-61.

11 C.V. Atchkinson, A Collection of Treaties, Engagements and Neighbouring Countries, New Delhi: Central Publishing Branch, 1929, pp. 173-75. 
his government's influence in Nepal and less a representative of a friendly country, and an ambitious Resident could find dozens of way in insinuating his influence into the affairs of the court to which he was accredited. ${ }^{12}$ Bhimsen Thapa had seen how the British Residents played decisive role in the subservience and incorporation of many Indian States into the British $R a j$, and thus was prepared to surrender some more areas to thwart the British scheme of stationing a representative at the Nepali court. But the British were not prepared to do so and David Ochterlony warned in unequivocal words, 'either you have a Resident or a war.' 13 The British General told the Nepali negotiator that all other points of the treaty were more or less open to subsequent discussion but no compromise would be made on the question of British Resident. ${ }^{14}$ Perhaps the British were convinced that through their Resident they could check the anti-British activities of the Nepal government, and the Resident also could explore the unknown routes of Nepal and put pressure on the Nepali statesmen to throw open their country for the British traders. Reluctantly the Nepali statesmen accepted the British formula and thus was fulfilled the long cherished ambition of the company's government. But the imposition of the Resident on the unwilling Nepali officials remained the greatest cause of jealousy and discontent of the Nepal government for decades to come, and more than anything else this particular provision of the treaty was nicknamed as dikkat (problem). ${ }^{15}$

\section{Period of Mutual distrust (1816-46)}

As noted earlier, the British had imposed a Resident at the Nepali Court in 1801. But it was short lived and, more than that, some restrictions were imposed on the working of the Resident. To quote the relevant portion of the treaty:

It is incumbent upon the Vakeels (representatives) of both states that exclusive of the supreme authorities and officers of government, they hold no meetings with any of the subjects or inhabitants of the country without the concurrence of the aforesaid authorities, neither should they carry on any

\footnotetext{
12 Ludwig F. Stiller, The Silent Cry: The People of Nepal (1816-39), Kathmandu: Sahayogi Prakashan, 1976, p. 227.

13 Kanchanmoy Mojumdar, Political Relations Between India and Nepal, New Delhi: Munshiram Manoharlal Publishers, 1973, p. 21.

14 Ramakant, Indo-Nepalese Relations, Delhi: S. Chand and Co., 1968, p. 40.

Ibid.,
} 
T.R.Manandhar: British Residents at the Court ...

correspondence with them, nor, in the event or their receiving any letter or writing from any such persons, should they return an answer, but they ought to disclose the particulars of such letter or writing to the aforesaid authorities by which means as all apprehension and doubt will be removed and the sincerity of friendship clearly manifested (Article 19). ${ }^{16}$

Compared to it, the position of the British Resident in 1816 was much stronger. No restrictions were imposed on the working of the Resident, and the treaty simply stated: 'In order to secure and improve the relations of amity and peace hereby established between the two states, it is agreed that accredited Ministers from each shall reside at the court of the other' (Article 8). Whenever the government of Nepal imposed any restrictions on the movements of the Resident, the latter complained of it as the violation of the treaty, and similarly any contact by the Resident with the junior officials or the opposition group was viewed as the unauthorized interference in the internal affairs of Nepal.

Edward Gardner, who as the commissioner of Kumaun had contacts with the Nepali statesmen and generals, was appointed Resident at Kathmandu, but pending his arrival, J.P. Boileau was sent to work an officiating Resident, possibly to avoid any doubt about the posting of the Resident. Boileau presented his credentials on 17 April 1816, and Gardner replaced him only after three months. Even after the arrival of Gardner, Bhimsen Thapa made his last bid to expel the British Resident with the Chinese help. It may be recalled that Nepal had requested Chinese help to fight the British. The Chinese refused to help Nepal, but after the ending of the war, the Chinese Emperor deputed his special envoy with a small force to Lhasa to review the post war situation. ${ }^{17}$ The Chinese help at this moment had no practical value since the war had already ended and the treaty had been signed, but Bhimsem exploited the opportunity to get rid of the British Resident and dispatched a mission of three senior officials to attend on the Chinese envoy at Shigatse. The mission reiterating Nepal's allegiance to the Chinese Emperor, requested for help to expel the British Resident from the Nepali capital. They argued that the presence of the British Resident at Kathmandu would endanger Sino-Nepali relations, and Nepal would not be able to send her quinquennial mission to China. Believing on what the Nepali officials argued, the Chinese envoy politely requested the Governor-General to

16 Text of the Treaty in Secret Consultation, 30 June 1802, no. 10, Indian National Archives ,INA, New Delhi.

17 John Pemble, The Invasion of Nepal, Oxford: Clarendon Press, 1972, p. 342. 
withdraw his Resident from the Nepali capital. ${ }^{18}$ To this request, Lord Hastings replied that the object of accredited minister to Nepal was solely to prevent the reoccurrence of the disputes and not to interfere in the external and internal affairs of that country. Pointing out that some restraining influence over Nepal was necessary, the Governor-General agreed to recall his agent if the Chinese Government sent its representative to replace him. ${ }^{19}$ The Chinese reply was that it was not the custom of the Imperial court to depute ambassadors, and with this the last attempt of the Nepal statesmen to send back the British Resident ended in failure. $^{20}$

Having failed to close down the Residency, Bhimsen Thapa decided to impose restrictions on the Resident's movements. The Nepali statesmen knew it well that the Resident, if allowed freely to mix with the people, would expose the secrets of the country and make her weak, which ultimately would reduce her to the status of a dominion state. So, the Resident's activities were closely watched through spies, and his movements were strictly restricted to a few miles inside the Kathmandu Valley. Only a week after he took charge of the Residency, Boileau reported:

A company of Sipahees have been ordered by Bhimsen Thapa to be dispersed between my house and the city during all hours, and to apprehend any person who may be thought to hold communication with me; and it has been given out in the city that any one so offending shall be punished. ${ }^{21}$

In his reply to this complaint, Lord Hastings admitted that it was 'certainly an indication of a very spirit of jealousy and suspicion', but expressed hope that once the Nepal government was convinced that their apprehensions were groundless these precautionary measures would be discontinued. Boileau was instructed that his conduct 'should be

18 Secret Consultation, 11 January 1817, no. 6, INA.

19 Pemble, f. n. no. 17, p. 344.

20 One writer says that, if the Chinese had seriously objected to the British presence in Nepal, the Resident would have been withdrawn, because the Company's government was in no mood to endanger the long-term interests of Anglo-Chinese maritime trade by giving offence. But the Chinese did not press the matter, and this Nepali ploy had no effect. Rishikesh Shah, Modern Nepal, Vol. I, New Delhi: Manohar, 1990, p. 147.

21 'Note on the position of Resident in Nepal' by F. Henvey dated 8 June 1877, Foreign Secret, December 1877, Foreign Secret, December 1877, no. 119 ,INA 
regulated on all occasions by a spirit of conciliation and prudence... to remove the characteristic jealousy of the Nepalese Government. ${ }^{22}$

When Gardner arrived at Kathmandu as the first British Resident, the situation was quite unfavorable to the British. The jealousy on the part of the Nepal government was at its height and the Resident had to live an isolated life. In an attempt to remove all future causes of misunderstanding and to strengthen the confidence of the Nepali people, Gardner cautiously moved with two-fold objectives. First, he tried to remain aloof from the internal politics of Nepal, and second, he constantly brought pressure to the Home government to give concessions to the Nepal government. In the latter objective, the Resident succeeded within a few months, when the company government restored the Tarai lands between the Gandak and Rapti rivers and between the Rapti and Koshi Rivers to Nepal. ${ }^{23}$ Although no radical changes in its behaviour could have been expected, the retrocession of Tarai produced a desirable effect on the Nepali Court. It helped in the execution of the treaty provisions and to some extent gave rise to much needed confidence in the minds of the Nepali people regarding the British intentions. ${ }^{24}$

Gardner's policy of non-interference was also equally successful. Reportedly, on several occasions, the opposition groups sought help from the Resident to oust Bhimsen Thapa from power. But Gardner turned deaf ear to them. His thirteen-year period was an era of calm and quiet diplomacy, when Anglo-Nepali relations remained almost undisturbed and minor issues were solved amicably.

Gardner resigned his post in 1829 and was succeeded by Herbert Maddock after two years, with B. H. Hodgson, as officiating Resident, taking charge of the Residency during the interval. Unlike Gardner, the new Resident, Maddock, was not satisfied with the existing situation. He complained that the intercourse between the Nepal government and the Resident had been confined in two public visits paid annually by the Resident to the king (one at Holi and the other at the Dasahara festival) and to two public visits by Bhimsen Thapa to the Resident. ${ }^{25}$ In addition, the Resident expressed his dissatisfaction over the suspicious nature of the Nepal government, and the isolation of the Resident. Maddock's ill health did not allow him to stay for a long period, and Anglo Nepali

Ibid.,

Ludwig F. Stiller SJ, The Rise of the House of Gorkha, Ranchi: The Patna Jesuit Society, 1975, p. 367.

24 Ramakant, f. n. no. 14, p. 63.

25 Foreign Secret, December 1877, no. 119, INA. 
relations entered into new phase in 1833 when Hodgson was appointed the Resident.

Hodgson was not a new face to the Nepali court. He was in the Residency service from 1820 and was in charge of the residency, as officiating Resident, for two years (1829-31). When he was appointed Resident, the political situation of Nepal was quite favourable to the British. The regent queen grandmother, who a staunch supporter of Bhimsen Thapa, had died and King Rajendra Bikram Shah had attained majority. These events weakened the dominating position of Bhimsen Thapa and it was an opportunity for the British to advance their long unfulfilled demands. To begin with, Hodgson demanded direct access and audience with the king, a privilege that had been denied so far. ${ }^{26}$ Bhimsen Thapa gave him the way, but the Resident himself had to realize that nothing could be achieved through the king alone. Thus, Hodgson continued his dealings with the Mukhtiyar, and demanded (a) free permission for the merchants to visit the Residency, (b) Marks of respect towards the Resident from the Nepali soldiers, and (c) freedom to the Resident to make excursions. ${ }^{27}$ The overall attitude of Bhimsen Thapa to these demands was negative, and thus Hodgson strongly recommended to the Home government to stop all intercourse with Nepal. The Home government, however, was not prepared to follow such an aggressive line, rather was waiting for a suitable opportunity to put pressure on the Nepali court. Hodgson was confirmed that such an opportunity would not come until Bhimsen Thapa dominated the politics of Nepal, and thus began playing diplomatic games to oust the Mukhtiyar from power. But contrary to his expectations, the situation was not favourable to the British even after the fall of Bhimsen Thapa in 1837. Ranga Nath, who succeeded Bhimsen Thapa continued the policy of the latter, and thus was branded by Hodgson as a 'dangerous' man. Rana Jang Pande, who came to power after Ranga Nath's exit, was more anti-British than his predecessors were, and so Hodgson called him vicious. ${ }^{28}$ It was only after his fall in November 1840 that the Resident could get what he wanted. The new government headed by Chautaria Fatteh Jang was favourably inclined towards the British government, and thus was nicknamed by other chiefs as 'British Ministry. ${ }^{29}$ From this time onwards, Hodgson was deeply involved in the internal affairs of Nepal, and it is said that the

\footnotetext{
26 Secret Consultation, 5 March 1833, no. 24, INA.

27 Foreign Secret, December 1877, no. 119, INA.

28 Foreign Consultation, 9 October 1837, no. 45 ,INA

29 Capt. T. Smith, Narrative of Five Years Residence at Nepal, London: Colburn, 1852, p. 97.
} 
Mukhtiyar, in order to inspire confidence of the Resident in himself, used to discuss with him in advance all state measures and policies, which were later adopted by his government. ${ }^{30}$ The British interference reached its climax in January 1841 when prominent members of the Nepali cabinet 'who had disturbed the friendly feelings existing between the British and Nepal governments' were dismissed and Hodgson was glad to learn that the Nepali government was accused of having sold the country to the British. ${ }^{31}$

Hodgson's tactics did not last long. The company's Government opposed his ideas and policies, and reprimanded him on some major issues. Specially in the Kashi Nath case (April 1842) he was rebuked for having exceeded his authority beyond 'the just limits of the law of Nations and solemn Treaty' and was condemned for having evinced' a want of personal consideration for a friendly and independent sovereign. ${ }^{32}$ Hodgson tried to change his policy to the satisfaction of the Governor General but the company's government was not satisfied with him. He made several diplomatic moves to remain in Nepal but to no avail. $^{33}$

Henry Lawrence, who succeeded Hodgson in 1843 and remained in Nepal for two years, followed a policy of non-interference, as instructed by the Home Government. As mentioned in his own authority letter to Captain Wheeler, the Resident should remain aloof from the internal politics of Nepal until his country's interests demanded to take some action, should have his official relations limited only to the king and the head of the Government, and should behave like a friend with Crown Prince and other officials. ${ }^{34}$

\section{Era of Reconciliation (1846-77)}

30 Foreign Secret Consultation, 23 November 1840, no. 130, INA.

31 M. S. Jain, The Emergence of a New Aristocracy in Nepal, Agra: Sri Ram Mehra and co., 1972, pp. 27-28.

32 Ramakant, f. n. no. 14, p. 206.

33 At first Hodgson requested the Governor General for permission to remain in Nepal giving reason of his poor health, and then he appealed to King Rajendra to interfere on his behalf. Rajendra wrote a letter to Ellenborough requesting the continuation of Hodgson as Resident in Nepal, but the governor General ignored him. For details, See: W.W. Hunter, Life of Brian Houghton Hodgson, London: John Murry, 1896.

34 Text of the letter H.B. Edwards and H. Merivale, Life of Sir Henry Lawrence, London: Smith, Elder and Co., 1872. 
In 1846, Jang Bahadur, a little known noble, emerged as a powerful prime Minister of Nepal, after eliminating his rival groups through the Kot and Bhandarkhal massacres. The new Prime Minister needed British support and help to stabilize his family rule in the country, and thus was favourably inclined towards them. He knew well the decisive role of the British Resident in regularizing Anglo-Nepali relations, and thus wanted to satisfy the British representative by every possible means. Great courtesy was shown to him and sometime his advice was sought for. He was allowed to make tours of the Tarai and the border areas to inspect the boundary pillars and settle extradition cases; and he and his staff were invited to social celebrations and hunting trips. ${ }^{35}$ In the functional ceremonies, the Resident occupied his seat next to the Prime Minister and the Residency Surgeon next to the Commander-in-chief. ${ }^{36}$ The Nepali Prime Minister received the new Resident with full honour at Thankot (borderline of Nepali capital), and the latter was to visit the Residency for the periodical meetings with the former. In spite of being a Hindu state, Nepal allowed the Resident and his staff to celebrate the Christmas Day in a free atmosphere and the Nepal Government presented fruits, sweets, spices, and other food materials as Christmas gift to the Resident. ${ }^{37}$

On their part, the British Residents also acted in a likewise manner. Captain Ottley, the officiating Resident, strictly avoided mixing up with the politics of Nepal during the Kot and Bhandarkhal massacres, and even did not give political asylum to the Nepali king. ${ }^{38}$ Another Resident, C. Thoresby (1846-50), was most friendly with Jang Bahadur, and it was due to his efforts that the British did not give any help to exking Rajendra and recognized the new king, though after the delay of a few months. ${ }^{39}$ Thoresby also played major role in the arrangement of Jang's visit to England, as the representative of the Nepali king.

These mutual concessions, however, do not mean that Jang was fully satisfied with the behaviour of the British Resident, nor was the latter happy with the Nepal government. During his visit to England, Jang was about to present a memorandum before the British authorities to the effect that the Nepal government should have the right to correspond directly with the Home Government in case of its being dissatisfied with

\footnotetext{
35 Mojumdar, f. n. no. 13, p. 22.

36

'Seating Plan of the Meeting at Darbar' RNA, Kathmandu, File no. 37.

Unpublished Document in the possession of the writer.

38 Tri Ratna Manandhar 'Capt. Ottley and the Kot Massacre’ The Rising Nepal, 10 May, 1974, p. 4.

39 Jain, f. n. no. 31, pp. 89-92; Ramakant, f. n. no. 14, p. 244.
} 
the British Resident, who sometime acted in an 'arbitrary manner.' However, the Nepali Prime Minister did not submit any such memorandum when he realized that the British Government would not entertain such complaints. ${ }^{40}$

The brief honeymoon period between Jang Bahadur and the British Residents was over in 1856 when Resident George Ramsay declined to recognize the 'sovereign status' of Jang and to receive any representative from him. ${ }^{41}$ In retaliation, the Nepali Prime Minister once again placed several restrictions on the movement of the Resident and leveled a number of charges against Ramsay, with the demand of his recall by the British government. That is why Ramsay complained:

... neither the Resident nor the members of his suite can stir out without attendants, who spy upon and report all their movements to the Minister (Jang). They can not speak to a Nepalese official without his permission, except in the most casual manner, nor can they move further now than they did years ago long before Jung Bahadur was Minister, who is even more narrow minded in the respect than were his predecessors. $^{42}$

To this complaint, Jang told the Resident:

You can take our country if it pleases you to do so, but we will make no change in that policy, owing to the strict observance of which we believe that we have preserved our independence as a nation to the present time, unless you compel us to do son. ${ }^{43}$

The clash between the Nepali Prime Minister and the British Resident reached its climax when Ramsay was summoned to the presence of the Governor General to defend the charges leveled against him by Jang. The Resident refuted all the charges and Lord Canning (Governor-General), being satisfied with his innocence, informed the

$40 \quad$ Ramakant, f. n. no. 14, p. 250.

41 In 1856, Jang Bahadur got the post of Maharaja and the sovereignty of the two districts through a Lal-Mohar of the king. He then asked Ramsay to recognize him as a independent ruler. Ramsay declined to do so. For details: Jain, f. n. no. 31, p. 138.

42 Secret Consultation, 25 February 1859, no. 17, INA.

43 Foreign Secret, December 1877, no. 119, INA. 
Nepal government that 'having fully satisfied himself, that no blame attached to colonel Ramsay's official conduct as Resident, that officer would shortly resume his functions ... supported by the full and unshaken confidence of the Governor-General. ${ }^{44}$

Jang got a lesson for his quarrel with the British representative, and he, after some hesitation, conceded his defeat and agreed to receive the Resident with full honours. Upon his arrival at Kathmandu, Ramsay was given a cordial reception, and Jang personally paid a visit to him to apologize, and desired that the past be forgotten. ${ }^{45}$ Ramsay continued to remain in Nepal for about seven years, and during that period, neither the Prime Minister nor the Resident made any complaint against one another. It seems that Jang had given some liberal concessions on the movement of the Resident. In a state order of 1860, the prime Minister had instructed the officials concerned to be polite in their dealings with the Resident and his subordinates. They should arrest any one who showed disrespect to the Resident, but should simply report the matter to the Resident if any one of his suite did anything wrong. The old custom of accompanying the Resident during his walk continued but the official concerned was not asked to report about the Resident's activities. ${ }^{46}$

Richard Lawrence, who succeeded Ramsay in 1865, introduced the practice of making tours in the Tarai and the border areas. ${ }^{47}$ He later told a member of the India council that he never suffered any inconvenience from the guards deputed to the Residency and that he had a 'circle of from twenty to thirty miles to move anywhere he liked. ${ }^{48}$

Charles Girdlestone made a break through shortly after his arrival at Kathmandu as British Resident in 1872. He made an agreement with Jang, according to which, throughout the valley of Kathamndu neither the Resident and the Residency Surgeon nor their families shall be accompanied by a Mookia except in the cities of Kathmandu, Patan, and Bhatgaon, or on visiting a crowded fair. ${ }^{49}$ The system of accompanying

44 'Memorandum of Political Relations' Prepared by George Ramsay, Foreign Political B, March 1875, INA.

45 Political Consultation, 30 December 1858, no. 603, INA.

46 State order dated 1917 B.S. Ashad Sudi 15 Roj 3 (3 July 1860), Ministry of Foreign Affairs, Kathmandu (MFA), Poka no. 14.

47 Foreign Secret, December 1877, no. 119, INA.

48 'Political and Secret Dispatches to India' Vol. 4 no. 6, India office Library, London, quoted in Mojumdar, f. n. no. 13, p. 29

49 Letter from Girdlestone to Ranaudip, 2 February 1880, MFA, Unnumbered bundle. 
the Resident or his subordinates in their visits beyond the Kathmandu Valley, however, was continued.

Thus, the 31-year rule of Jnag Bahadur was an era of reconciliation between the British Residents and the Nepal Government. The latter gave some liberal concessions and the former had to admit that their position in Nepal differed from that of the Indian states. To put it in the words of the then Residency Surgeon, Daniel Wright:

The position of the Resident in Nepal is a somewhat peculiar one. It differs from similarly named appointments in the protected states of India in this, that in Nepal the Resident has nothing whatever to do with the Government of the country. In fact, he merely acts as consul, in the same way as the British consul at any European Court. The Nepalese are particularly proud of their independence, and most jealous of any interference with their domestic policy. ${ }^{50}$

\section{Decades of Frustration and Compromise (1877-1901)}

Jang Bahadur died in 1877 and was succeeded by his weak brother, Ranaudip Singh. The British had hopes that the new Prime Minister would be more liberal in his attitude towards the British Resident. But contrary to expectations, Ranaudip Singh continued the old policy of exclusion and rather tightened it.

In order to test the attitude of the new government, F. Henvey (working as officiating Resident during the absence of Girdlestone) made a proposal to visit Tatopani, northeast of Kathmandu. But, as expected, the Nepal government rejected the proposal on the ground that no previous Residents had ever been to that place. The Resident complained that a diplomatic envoy had been deprived of 'international custom and courtesy' and of 'equity and reciprocity.' He claimed the right to travel within the country 'to which I was accredited. ${ }^{51}$ Henvey also protested against (a) the restrictions placed upon the Resident's freedom of excursion beyond a few miles from the capital (b) the system of espionage by which the Resident and the Residency was surrounded and (c) the social isolation in which the Resident was kept owing to the jealous precautions adopted by the Durbar. ${ }^{52}$ The British Resident

50 Daniel Wright, History of Nepal, Cambridge: Cambridge University press, 1879, p. 71.

51 Foreign Secret, December 1877, no. 117I NA.

52 Ibid., no. 118. 
recommended to the Indian Viceroy to make a formal demand on the matter and suggested to withdraw the Resident, should the Nepal government take a tough attitude.

Lord Lytton was in favour of taking official action to make the position of the Resident better, but his council opposed it. Finally, the Resident was instructed to drop the matter but to remind the Prime Minister of Nepal that 'thought discussion is discontinued, the view of the British government remain unchanged and its demands unwithdrawn. ${ }^{53}$

After resuming his charge as Resident, Girdlestone made another attempt. During his annual inspection tour of the frontier, he ventured to make a tour of Dang and Deukhuri Valleys, where no European had set foot before, without getting permission of the Nepal government. But the district governor did not permit him to enter the valley and demanded to produce a passport issued by the Nepal government. Girdlestone got the pretext and demanded for immediate and ample apology from the Prime Minister for the discourtesy evinced by his officials to the British representative at his court. $^{54} \mathrm{He}$ recommended that the British government should deprive the Nepali subjects, in the way of retaliation, of the trade facilities in the British territory. But before anything could happen, Ranaudip promptly apologized for the incident with the assurance that the concerned governor had been reprimanded, and the issue was over. ${ }^{55}$

Having failed to open new places (outside the Kathamndu Valley) to the Europeans, Girdlestone placed his old demand to end the system of accompanying the Resident by Nepali guards during his morning and evening walks. The prime Minister replied that he would take necessary action if the system caused any 'gross' inconvenience to the Resident. Girdlestone followed a different method to justify his inconvenience. He quarreled with the guards who were on their duty to accompany the Resident outside the Residency limits. The guards did not follow any submissive method rather claimed that they were to follow him 'on the orders from the Durbar. ${ }^{56}$ The Resident exploited the opportunity and warned the Nepal government that' to attempt to force on me an arrangement which was personally distasteful and which I have proved unnecessary was quite inconsistent with the profession of

53 Ibid., no. 120.

54 Foreign Political A, October 1879, no. 51 ,INA.

55 Ibid., no. 53.

56 Note by the Orderly Officer, 1936 V.S. Ashad Badi 30 Roj 5 (19 June 1879), MFA, Poka no. 30. 
friendship for the British government which the Darbar was so fond of making.' Girdlestone also complained that the 'present government is not giving that much liberty as was given by Sir Jung Bahadur. ${ }^{57}$

The forcible attitude of the British Resident compelled the Nepal government to consider the matter seriously. Finally, a compromise was reached, according to which the Nepali guards should accompany the Resident only in his long tours during the festivals but not in his morning and evening walks. ${ }^{58}$

The death of the Nepali king in 1881 provided one more opportunity to Girdlestone to advance his old grievances. He recommended to the Indian Viceroy to delay the recognition of the new king, unless some of his old demands were fulfilled. The Resident also refused to pay Nuzzur to and receive Khillut from the new king, arguing the former as an offering of an inferior and the latter as a gift of the superior. ${ }^{59}$

Lord Ripon, who was against any forward policy, followed a policy of compromise. He recognized the new king of Nepal and instructed the Resident to obey the rule prevailing since 1816 (question of Nuzzar \& Khillut). At the same time the Prime Minister was also asked to treat the Resident 'with strict courtesy and in conformance with recognized etiquette. ${ }^{60}$

Encouraged by the positive attitude of the Indian Viceroy, Ranaudip Singh submitted a memorandum to the Indian Foreign Secretary to be presented before the Indian Viceroy, in which the Nepali Prime Minister had leveled several charges against Girdlestone. ${ }^{61}$ The foreign office of India discussed the memorandum thoroughly and defended the Resident on almost all the charges. Calling it 'the treacherous attack on the viceroy's representative', the memorandum was not placed before the Viceroy and the entire matter was laid to rest. ${ }^{62}$

57 Foreign Political B, March 1880, no. 188, INA.

58 Nepal Residency Records, File no. 1225 G of 1879 (part II), MFA Unnumbered Poka (Letter from Ranaudip to Girdlestone 28 December 1879).

59 Note by T. Hope dated 14 July 1881, Foreign Secret, April 1882, K.W. of nos. 32-79, INA.

60 Ibid., no. 69.

61 Memo Presented by Khadga Shamsher to Indian foreign secretary, 1940 V.S. Magh Badi 10, Roj 3 (22 Jan 1884) MFA, Poka no. 97.

62 Note by a Foreign Department official dated 16 January 1884, Foreign Secret, February 1884, K.w. 1 of no. 62-66, INA. 
Thus, the nine-year rule of Ranaudip Singh (1877-85) was a period of frustration to the British Resident in Nepal. Particularly, Girdlestone was worried that his old demands remained unfulfilled.

The struggle inside the ruling family led to a coup in 1885, in which the Prime Minister was assassinated and his nephews captured power. At the time of coup, Girdlestone was on leave and colonel Barkeley was working as officiating Resident. The new Prime Minsiter, Bir Shamsher needed British support to stabilize his rule and thus gave some liberal concessions to the British in all fields. Impressed by the positive attitude of Bir Shamsher, the British recognized the new administration of Nepal within a short period. However, the situation changed after Girdlestone resumed his post in 1886. Having a long experience of Nepali politics, the Resident was not satisfied with minor concessions, and in order to put pressure on the new administration, he supported and helped the opposition group, who had taken shelter in India, against the Prime Minister. Bir Shamsher was so annoyed with the Resident that he is alleged of a secret plan to kill the Resident and make an attack on the Residency. ${ }^{63}$ Under these circumstances, Girdlestone was obliged to resign his post in 1888.

The replacement of the Resident did not solve the problem. The new Resident, E.L. Durand, was also an advocate of 'Strong policy' towards Nepal, and thus formed a very bad opinion of Bir Shamsher's rule. ${ }^{64}$ He complained that the prime Minster did not communicate him the accurate information and was playing China against the British, and thus recommended to censure Bir Shamsher. ${ }^{65}$ The Indian Viceroy was not in favour of taking any strong measure and so he replaced Durand by $\mathrm{H}$. Wylie, who was strictly instructed to adopt a policy of conciliation and compromise. Wylie assured the viceroy that his main duty would be 'to endeavour to bring about a better understanding between ourselves and the Darbar. ${ }^{, 66}$

Wylie admitted that the Nepal government did not trust the British motives, but at the same time remarked that the British had been equally suspicious of the Nepali statesmen. Thus, he adopted a policy of mutual concession to win the confidence of the Nepal government. The Resident's policy proved to be successful. He inaugurated the changes by

63 Note by the Head Clerk of the Residency dated 31 December 1887, Foreign Secret E, February 1888, no. 79, INA.

64 Asad Hussain, British India's Relations with the Kingdom of Nepal. London: George Allen and Unwin, 1970, p. 133.

65 Foreign Secret E, October 1890, nos. 88-89, INA.

66 Husain, f. n. no. 64, p. 135. 
which suspicion lessened and friendship grew between the two states. This is evident from a report by his successor, W. Loch, in 1900, which, in part, reads:

I believe the Darbar is inclined to relax its policy of mistrust, certainly the Resident is not dogged about by spies to the extent of complained of formerly, and a certain amount of latitude is extended to me in allowing me to visit parts of the country off the beaten track of visitors for the purpose of fishing. I am inclined to follow my predecessor's plan, which was to work patiently to win the Darbar's confidence, rely on it for information and retrain from trying to obtain information through channels of my own. ${ }^{67}$

\section{Concluding Remarks}

The Sugauli Treaty (1816) mentions that the 'accredited Ministers from each side shall reside at the court of the other.' The Nepali ministers at Calcutta (know as Vakil) formed no part of debate, but the British ministers at Katmandu (known as Resident) always remained a subject of controversy. The provision of British Resident did not impair the independent status of Nepal but in real practice in was not so. The Resident was less a representative of a friendly nation and more a watchdog to expand his government's influence in Nepal. The Nepal government always looked upon him with suspicion, whereas the Resident asserted his 'supreme' right as the representative of a powerful nation. Mutual trust and confidence were always lacking in them. But one thing is clearly visible that whenever the Resident behaved in a friendly manner, the Nepali statesmen responded in similar fashion and vice versa. Gardener's 13-year period was quite peaceful because he adopted every possible means to win the confidence of the Nepal Darbar, but Hodgson did not succeed in his objectives ${ }^{68}$ since he tried to impose everything by threat, and openly attempted to interfere in the internal politics of Nepal. During Jang Bahadur's rule, the internal politics and Anglo-Nepali relations were complimentary to one another. Thoserby could win the favour of Jang because the former defended the latter in

67 Foreign Secret E, July 1990, no. 284 (Report by W. Loch dated 11 June 1900), INA.

68 Stiller, f. n. no. 12, p. 244. Hodgson achieved no relaxation of the restrictions placed on his movement in and around Kathmandu. He got no trade treaty. He was unable to achieve an extradition treaty. He not only failed to force Bhimsen Thapa to implement the trade treaty of 1792, but saw the Governor General permit Bhimsen Thapa to abrogate it officially. 
almost all cases, but Ramsay had a severe clash with the Prime Minister, when he did not recognize the latter as a 'sovereign ruler.'

Girdlestone remained as Resident at the court of Nepal for the longest period. Shortly after his arrival, the Resident could win the favour of Jang, leading to the relaxation of some restrictions on his movement. But his formula did not last long, since he did not fulfill the demands of Nepal government. During Ranaudip's rule, Girdlestone had personal clash with the prime Minister on minor issues, which were made serious by the Resident himself. ${ }^{69}$ The same situation repeated during Bir's Prime Minsitereship, when Girdlestone openly supported the opposition camp, and the Prime Minister even thought of killing the British representative secretly. Wylie must be given credit for improving the position of British Resident in Nepal. His policy of conciliation and compromise succeeded to erase mutual distrust and enmity and finally led to the recognition of Nepal's independent status by the British.

Regarding the attitude of the British government, at no time did it encourage interfering in the domestic politics of Nepal. But many times, it could not ignore the voice of the Resident who had close and direct contact with the Nepali statesmen and people. Contemporary documents hinted that on some occasions, Viceroy Auckland was reluctant to support Hodgson's plans and policies, but he was compelled to do so, as he had no clear knowledge about Nepal. But Ellenborough did not follow his path and got Hodgson removed from office at a single stroke. Similarly, Girdlestone had been reprimanded on many cases for his 'injudicious' activities, but the Indian Viceroy was not prepared to condemn him in open for it would decrease the supreme status of the British government in Nepal. ${ }^{70}$

To sum up, the British Residents and the Nepal government followed a 'tit for tat' policy throughout the nineteenth century. Whenever Nepal adopted a tough line, the British reacted in similar way, but once the Nepal government cooperated with the British, the latter's attitude was most positive. Involved in this 'give and take' game were the self-interests of the Nepal's statesmen (not the country's interests), the imperialistic designs of the British, and the personal ambition of the Residents.

$$
* * *
$$

69 For details, see Manandhar, f. n. no. 3, pp. 216-18.

70 'Political and Secret Dispatches to India', Vol. 6 no. 16, India Office Library, London, quoted in Mojumdar, f. n. no. 13, p. 31. 